\title{
The De Rossett Farm (41HE75) and Quate Place (41HE81) Sites in the Cobb Creek Valley in the Upper Neches River Basin, Henderson County, Texas
}

Timothy K. Perttula

Heritage Research Center, Stephen F. Austin State University

Follow this and additional works at: https://scholarworks.sfasu.edu/ita

Part of the American Material Culture Commons, Archaeological Anthropology Commons, Environmental Studies Commons, Other American Studies Commons, Other Arts and Humanities Commons, Other History of Art, Architecture, and Archaeology Commons, and the United States History Commons

Tell us how this article helped you.

This Article is brought to you for free and open access by the Center for Regional Heritage Research at SFA ScholarWorks. It has been accepted for inclusion in Index of Texas Archaeology: Open Access Gray Literature from the Lone Star State by an authorized editor of SFA ScholarWorks. For more information, please contact cdsscholarworks@sfasu.edu. 


\section{The De Rossett Farm (41HE75) and Quate Place (41HE81) Sites in the Cobb Creek Valley in the Upper Neches River Basin, Henderson County, Texas}

\section{Creative Commons License}

\section{(c) (1) (8)}

This work is licensed under a Creative Commons Attribution-NonCommercial 4.0 International License 


\title{
The De Rossett Farm (41HE75) and Quate Place (41HE81) Sites in the Cobb Creek Valley in the Upper Neches River Basin, Henderson County, Texas
}

\author{
Timothy K. Perttula
}

\section{Introduction}

The De Rossett Farm and Quate Place sites were among the earliest East Texas archaeological sites to be investigated by professional archaeologists at The University of Texas (UT), which began under the direction of Dr. J. E. Pearce between 1918-1920 (Pearce 1920a, 1920b, 1932a, 1932b, and 1932c). According to Pearce (1932c:51), UT began work in this part of the state under the auspices of the Bureau of American Ethnology, and that work "had led me to suppose that I should find this part of the State rich in archeological material of a high order."

The two sites were investigated in August 1920. They are on Cobb Creek, a small and eastwardflowing tributary to the Neches River (Figure 1), nor far to the northeast of the town of Frankston, Texas (Pearce 1920a); the sites are across the valley from each other. The De Rossett Farm site is on an upland slope on the north side of the valley, while the Quate Place site is on an upland slope on the south side of the Cobb Creek valley, about $2 \mathrm{~km}$ west of the Neches River, and slightly southeast from the De Rossett Farm. Both sites have domestic Caddo archaeological deposits, and there was an ancestral Caddo cemetery of an unknown extent and character at the De Rossett Farm.

\section{Archaeological Investigations at the De Rossett Farm (41HE75)}

The site had been discovered around 1914-1915 during road construction. Plowing of the road ditch had exposed numerous ceramic vessels. Some time prior to 1920, perhaps in 1919, a Judge A. B. Watkins from Athens, Texas, excavated these Caddo ceramic vessels, and also recovered two ceramic pipes, and a large chipped stone knive; the pipes had apparently been found in two separate burials, placed near the chest and hip of the deceased. These artifacts were purchased by Pearce in 1920, and are in the collections of the Texas Archeological Research Laboratory, The University of Texas at Austin.

In August 1920, Pearce, with the assistance of George Engerrand, also carried out excavations in the cemetery area at the De Rossett Farm. These excavations consisted of trenches that were $3 \mathrm{ft}$. deep and spaced $15 \mathrm{ft}$. apart across the cemetery. During that work, ceramic vessels, two ceramic pipes, two arrow points and a chipped stone knive, two conch shell fragments (one with its end ground to a point), and a small piece of hammered lead were recovered from an unknown number of burial features. It appears that 12 specimens from this cemetery excavation were sent to the U.S. National Museum (the precursor to the National Museum of Natural History [NMNH] at the Smithsonian Institution) because of the fact that funds used in the UT excavations had been furnished by Dr. J. W. Fewkes of the Bureau of American Ethnology. The current provenance of these material remains is not known with any certainty, and there are no De Rossett Farm collections listed for Henderson County in the NMNH records (Dorothy Lippert, personal communication, September 28, 2015).

\section{Ceramic Vessels}

There are nine ceramic vessels from the De Rossett Farm site that came from the Judge A. B. Watkins collection. They include bottles $(n=2)$, bowls $(n=3)$, jars $(n=1)$, compound bowls $(n=1)$, and carinated bowls $(n=2)$; all of the vessels are grog-tempered. The decorated methods and elements on the vessels indicate that they came from Frankston phase burial features. 


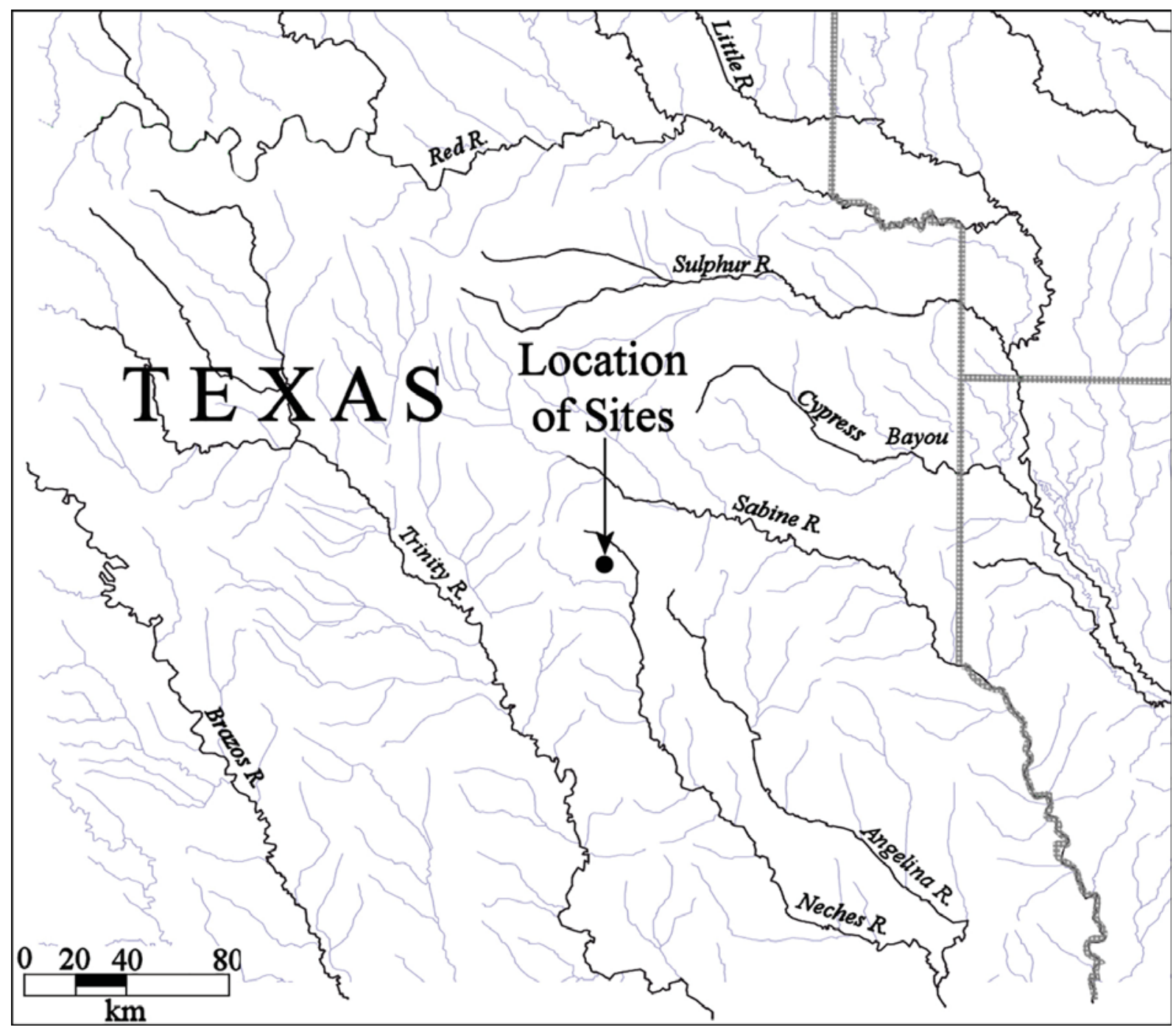

Figure 1. Location of the De Rossett Farm and Quate Place sites in East Texas.

SITE NAME OR SITE NUMBER: De Rossett Farm

VESSEL NO.: 13

VESSEL FORM: Bottle with a short neck

NON-PLASTICS AND PASTE: grog

RIM AND LIP FORM: direct rim and rounded lip

CORE COLOR: A (fired and cooled in an oxidizing environment)

INTERIOR SURFACE COLOR: light yellowish-brown

EXTERIOR SURFACE COLOR: light yellowish-brown; fire clouds on the neck and body

WALL THICKNESS (IN MM): rim, $8.8 \mathrm{~mm}$ 
INTERIOR SURFACE TREATMENT: none

EXTERIOR SURFACE TREATMENT: none

HEIGHT (IN CM): 24.1

ORIFICE DIAMETER (IN CM): 4.2

DIAMETER AT BOTTOM OF RIM OR NECK (IN CM): 5.4; maximum body diameter is $11.5 \mathrm{~cm}$

BASE DIAMETER (IN CM) AND SHAPE OF BASE: 7.6; circular and flat

ESTIMATED VOLUME (IN LITERS): 0.74

DECORATION (INCLUDING MOTIF AND ELEMENTS WHEN APPARENT): The vessel body has a continuous series of vertical rows of tool punctations from the bottom of the vessel neck to the vessel base.

PIGMENT USE AND LOCATION ON VESSEL: none

TYPE AND VARIETY (IF KNOWN): cf. Hume Punctated

SITE NAME OR SITE NUMBER: De Rossett Farm

VESSEL NO.: 14

VESSEL FORM: Bowl with a small tab tail or lip lug opposite a broken area along the rim that may have had an effigy head attachment.

NON-PLASTICS AND PASTE: grog

RIM AND LIP FORM: Direct rim and rounded lip

CORE COLOR: $\mathrm{G}$ (fired in a reducing environment and cooled in the open air)

INTERIOR SURFACE COLOR: light grayish-brown

EXTERIOR SURFACE COLOR: brown

WALL THICKNESS (IN MM): rim, $4.9 \mathrm{~mm}$

INTERIOR SURFACE TREATMENT: smoothed

EXTERIOR SURFACE TREATMENT: burnished

HEIGHT (IN CM): 3.1

ORIFICE DIAMETER (IN CM): 8.2

DIAMETER AT BOTTOM OF RIM OR NECK (IN CM): N/A 
BASE DIAMETER (IN CM) AND SHAPE OF BASE: 2.5; circular and flat

ESTIMATED VOLUME (IN LITERS): 0.1

DECORATION (INCLUDING MOTIF AND ELEMENTS WHEN APPARENT): The vessel is decorated with two horizontal engraved lines below the vessel lip.

PIGMENT USE AND LOCATION ON VESSEL: none

TYPE AND VARIETY (IF KNOWN): cf. Hood Engraved

SITE NAME OR SITE NUMBER: De Rossett Farm

VESSEL NO.: 15

VESSEL FORM: Jar with two opposed lugs (20 x $22 \mathrm{~mm}$ in length and width)

NON-PLASTICS AND PASTE: grog

RIM AND LIP FORM: Direct rim and rounded lip

CORE COLOR: G (fired in a reducing environment and cooled in the open air)

INTERIOR SURFACE COLOR: very dark grayish-brown

EXTERIOR SURFACE COLOR: light yellowish-brown; fire clouds on the rim, body, and base

WALL THICKNESS (IN MM): rim, $7.7 \mathrm{~mm}$

INTERIOR SURFACE TREATMENT: smoothed

EXTERIOR SURFACE TREATMENT: none

HEIGHT (IN CM): 15.1

ORIFICE DIAMETER (IN CM): 14.6

DIAMETER AT BOTTOM OF RIM OR NECK (IN CM): 14.6

BASE DIAMETER (IN CM) AND SHAPE OF BASE: 6.4; circular and flat

ESTIMATED VOLUME (IN LITERS): 1.3

DECORATION (INCLUDING MOTIF AND ELEMENTS WHEN APPARENT): The vessel is decorated with horizontal brushing marks on the rim, and vertical, opposed, and horizontal brushing marks on the vessel body. The brushing marks on the body extend to within $2.5 \mathrm{~cm}$ of the vessel base.

PIGMENT USE AND LOCATION ON VESSEL: none

TYPE AND VARIETY (IF KNOWN): Bullard Brushed 
SITE NAME OR SITE NUMBER: De Rossett Farm

VESSEL NO.: 16

VESSEL FORM: globular Carinated bowl

NON-PLASTICS AND PASTE: grog

RIM AND LIP FORM: Everted rim and rounded lip

CORE COLOR: A (fired and cooled in an oxidizing environment)

INTERIOR SURFACE COLOR: light reddish-brown; fire clouds on the body and base

EXTERIOR SURFACE COLOR: light reddish-brown; fire clouds on the rim, body, and base

WALL THICKNESS (IN MM): rim, $6.2 \mathrm{~mm}$

INTERIOR SURFACE TREATMENT: smoothed

EXTERIOR SURFACE TREATMENT: smoothed

HEIGHT (IN CM): 13.2

ORIFICE DIAMETER (IN CM): 12.8

DIAMETER AT BOTTOM OF RIM OR NECK (IN CM): 14.2

BASE DIAMETER (IN CM) AND SHAPE OF BASE: 8.7; circular and flat

ESTIMATED VOLUME (IN LITERS): 1.5

DECORATION (INCLUDING MOTIF AND ELEMENTS WHEN APPARENT): The rim panel is defined by single upper and lower horizontal engraved lines. The panel is divided into four oval sections by four excised bracket elements (Figure 2).

PIGMENT USE AND LOCATION ON VESSEL: none

TYPE AND VARIETY (IF KNOWN): Poynor Engraved, var. Hood (Perttula 2011:Figure 6-64e)

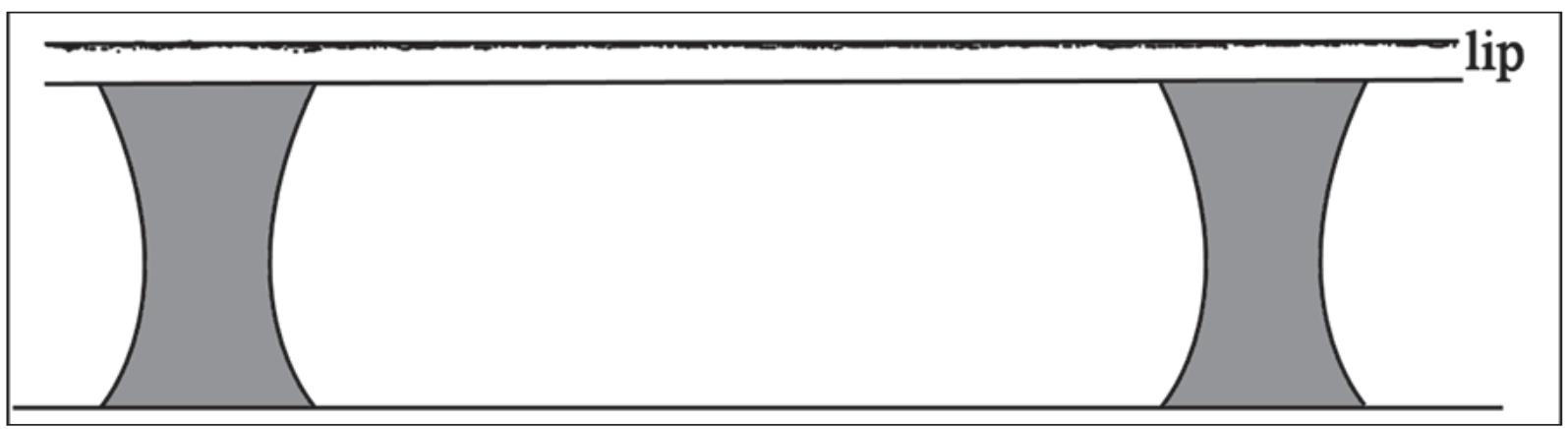

Figure 2. Decorative elements on Poynor Engraved, var. Hood (No. 16) carinated bowl from the De Rossett Farm site. 
SITE NAME OR SITE NUMBER: De Rossett Farm

VESSEL NO.: 17

VESSEL FORM: Carinated bowl

NON-PLASTICS AND PASTE: grog

RIM AND LIP FORM: Inverted rim and rounded lip

CORE COLOR: A (fired and cooled in an oxidizing environment)

INTERIOR SURFACE COLOR: yellowish-brown

EXTERIOR SURFACE COLOR: yellowish-brown; fire clouds on the body

WALL THICKNESS (IN MM): rim, $7.0 \mathrm{~mm}$

INTERIOR SURFACE TREATMENT: smoothed

EXTERIOR SURFACE TREATMENT: burnished

HEIGHT (IN CM): 16.4

ORIFICE DIAMETER (IN CM): 23.5

DIAMETER AT BOTTOM OF RIM OR NECK (IN CM): 23.7

BASE DIAMETER (IN CM) AND SHAPE OF BASE: 8.0; circular and flat

ESTIMATED VOLUME (IN

LITERS): 3.5

DECORATION (INCLUDING MOTIF AND ELEMENTS WHEN

APPARENT): The rim has an engraved panel defined by single upper and lower horizontal engraved lines. The panel is divided into 10 oval-shaped sections by a series of 10 excised bracket elements (Figure 3 ). The vessel body is decorated with horizontal brushing marks.

PIGMENT USE AND LOCATION ON VESSEL: none

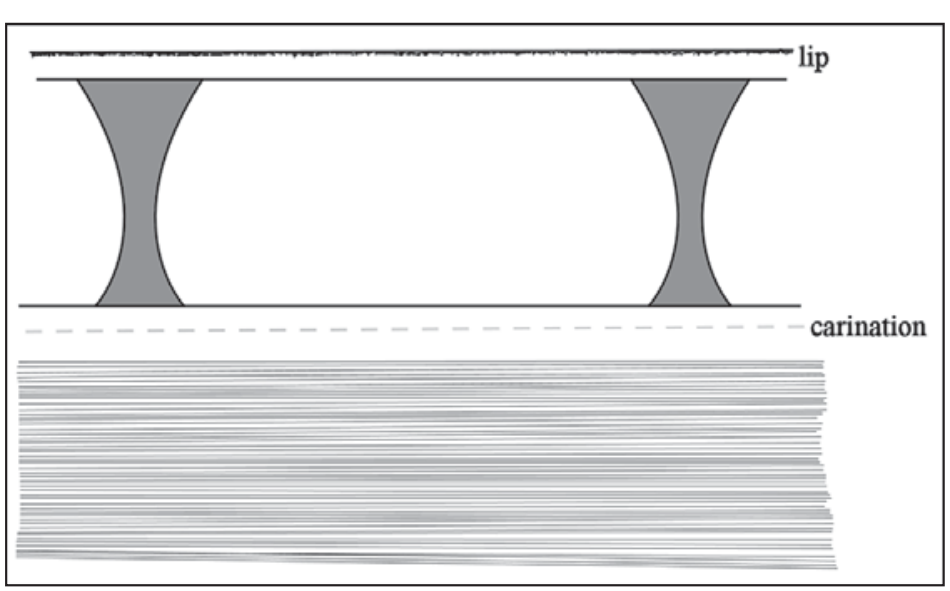

Figure 3. Decorative elements on Poynor Engraved, var. Hood carinated bowl (No. 17) from the De Rossett Farm site.

TYPE AND VARIETY (IF KNOWN):

Poynor Engraved, var. Hood 
SITE NAME OR SITE NUMBER: De Rossett Farm

VESSEL NO.: 18

VESSEL FORM: Compound bowl

NON-PLASTICS AND PASTE: grog

RIM AND LIP FORM: Everted rim and rounded lip

CORE COLOR: G (fired in a reducing environment and cooled in the open air)

INTERIOR SURFACE COLOR: very dark grayish-brown

EXTERIOR SURFACE COLOR: dark reddish-brown; fire clouds on the rim and body

WALL THICKNESS (IN MM): rim, $5.3 \mathrm{~mm}$

INTERIOR SURFACE TREATMENT: smoothed on the upper panel

EXTERIOR SURFACE TREATMENT: burnished

HEIGHT (IN CM): 10.2

ORIFICE DIAMETER (IN CM): 16.2

DIAMETER AT BOTTOM OF RIM OR NECK (IN CM): 16.5

BASE DIAMETER (IN CM) AND SHAPE OF BASE: 7.0; circular and flat

ESTIMATED VOLUME (IN LITERS): 1.3

DECORATION (INCLUDING MOTIF AND ELEMENTS WHEN APPARENT): The upper panel of the vessel is plain, but the lower panel has a series of six sets of concentric semi-circles around a central circle element (Figure 4). The lower panel is delimited by single upper and lower horizontal engraved lines.

PIGMENT USE AND LOCATION ON VESSEL: none

TYPE AND VARIETY (IF KNOWN): cf. Poynor Engraved, var. Lang (Perttula 2011:Figure 6-64)

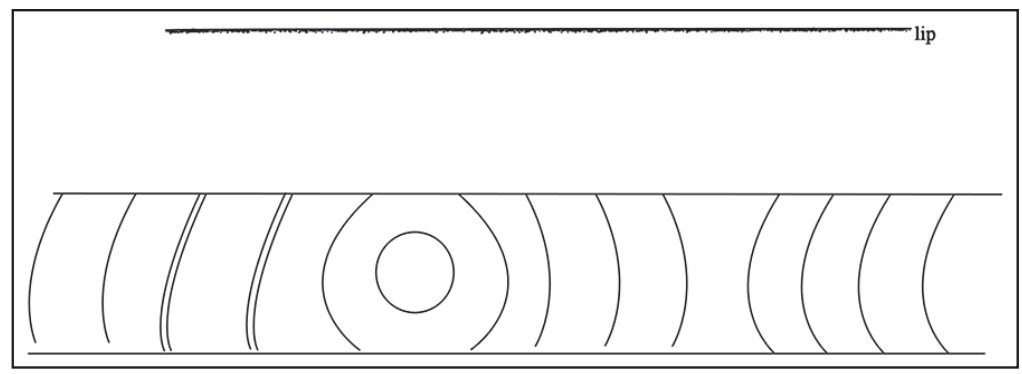

Figure 4. Decorative elements on cf. Poynor Engraved, var.

Lang compound bowl (No. 18) from the De Rossett Farm site. 
SITE NAME OR SITE NUMBER: De Rossett Farm

VESSEL NO.: 19

VESSEL FORM: Bowl with five appliqued lip nodes (21 mm in width)

NON-PLASTICS AND PASTE: grog

RIM AND LIP FORM: Direct rim and rounded lip

CORE COLOR: G (fired in a reducing environment and cooled in the open air)

INTERIOR SURFACE COLOR: grayish-brown

EXTERIOR SURFACE COLOR: brown; fire clouds on the rim, body, and base

WALL THICKNESS (IN MM): rim, $7.2 \mathrm{~mm}$

INTERIOR SURFACE TREATMENT: smoothed

EXTERIOR SURFACE TREATMENT: burnished

HEIGHT (IN CM): 9.5

ORIFICE DIAMETER (IN CM): 20.8

DIAMETER AT BOTTOM OF RIM OR NECK (IN CM): N/A

BASE DIAMETER (IN CM) AND SHAPE OF BASE: 7.0; circular and flat

ESTIMATED VOLUME (IN LITERS): 0.8

DECORATION (INCLUDING MOTIF AND ELEMENTS WHEN APPARENT): The vessel is decorated with three broad horizontal engraved lines below the vessel lip.

PIGMENT USE AND LOCATION ON VESSEL: none

TYPE AND VARIETY (IF KNOWN): Hood Engraved 
SITE NAME OR SITE NUMBER: De Rossett Farm

VESSEL NO.: 21

VESSEL FORM: Bowl

NON-PLASTICS AND PASTE: grog

RIM AND LIP FORM: Inverted rim and rounded lip

CORE COLOR: B (fired and cooled in a reducing environment)

INTERIOR SURFACE COLOR: dark grayish-brown

EXTERIOR SURFACE COLOR: dark grayish-brown; fire clouds on the rim and body

WALL THICKNESS (IN MM): rim, $5.0 \mathrm{~mm}$

INTERIOR SURFACE TREATMENT: none

EXTERIOR SURFACE TREATMENT: smoothed

HEIGHT (IN CM): 4.1

ORIFICE DIAMETER (IN CM): 5.7

DIAMETER AT BOTTOM OF RIM OR NECK (IN CM): 7.4

BASE DIAMETER (IN CM) AND SHAPE OF BASE: 7.4; circular and rounded

ESTIMATED VOLUME (IN LITERS): 0.1

DECORATION (INCLUDING MOTIF AND ELEMENTS WHEN APPARENT): The vessel is decorated with a series of six short and narrow vertical engraved panels (Figure 5). These panels are filled with diagonal and diagonal opposed engraved lines or zig-zag lines.

PIGMENT USE AND LOCATION ON VESSEL: none

TYPE AND VARIETY (IF KNOWN): Poynor Engraved, var. unspecified

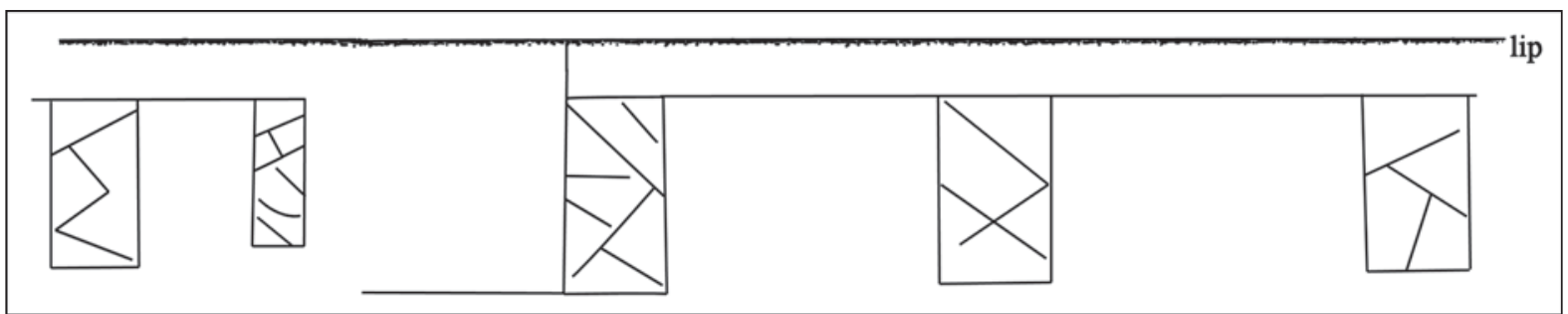

Figure 5. Poynor Engraved, var. unspecified bowl (No. 21) from the De Rossett Farm site. 
SITE NAME OR SITE NUMBER: De Rossett Farm

VESSEL NO.: 22

VESSEL FORM: Bottle with a straight neck and a carinated body

NON-PLASTICS AND PASTE: grog

RIM AND LIP FORM: Direct rim and rounded lip

CORE COLOR: G (fired in a reducing environment and cooled in the open air)

INTERIOR SURFACE COLOR: dark grayish-brown

EXTERIOR SURFACE COLOR: light yellowish-brown; fire clouds on the rim, body, and base

WALL THICKNESS (IN MM): rim, $6.8 \mathrm{~mm}$

INTERIOR SURFACE TREATMENT: none

EXTERIOR SURFACE TREATMENT: smoothed

HEIGHT (IN CM): 24.3

ORIFICE DIAMETER (IN CM): 5.8

DIAMETER AT BOTTOM OF RIM OR NECK (IN CM): 6.9; maximum body diameter is $20.3 \mathrm{~cm}$

BASE DIAMETER (IN CM) AND SHAPE OF BASE: 8.9; circular and rounded

ESTIMATED VOLUME (IN LITERS): 0.9

DECORATION (INCLUDING MOTIF AND ELEMENTS WHEN APPARENT): There are several different engraved elements on the body of this vessel. Immediately below the neck are a series of excised pendant triangles above a single horizontal engraved line (Figure 6). Pendant from this engraved line are a series of four large, open pendant triangles with their apexes pointing towards the vessel base, and as a counterpoint to this engraved element are a series of another four much larger engraved pendant triangles whose apexes point towards the bottle neck. These large engraved pendant triangles have a series of three nested triangles marked by either short horizontal or diagonal hatched lines (Figure 6).

These upper and lower large pendant triangle elements divide the vessel body into four panels. The panels each have a series of concentric circles, with a small central circle element (Figure 6).

PIGMENT USE AND LOCATION ON VESSEL: none

TYPE AND VARIETY (IF KNOWN): Poynor Engraved, var. unspecified

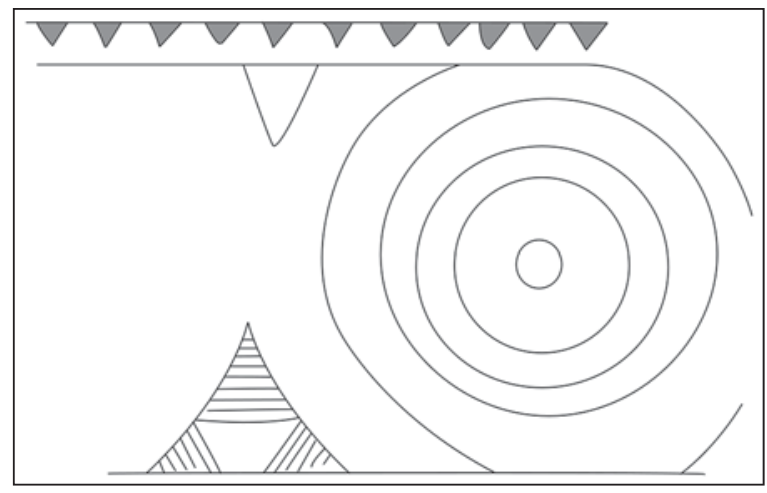

Figure 6. Poynor Engraved, var. unspecified bottle (No. 22) from the De Rossett Farm site. 


\section{Ceramic Pipe}

The one complete ceramic pipe in the TARL collections from the De Rossett Farm site is an elbow pipe with a ring pedestal base (Figure 7). The pipe has a deep bowl and a lengthy stem: its height, including the pedestal, is $53.0 \mathrm{~mm}$; its height without the pedestal base is $36.0 \mathrm{~mm}$. The length of the pipe is $80.2 \mathrm{~mm}$, the orifice diameter of the bowl is $48.8 \mathrm{~mm}$, the stem's orifice diameter is $23.5 \mathrm{~mm}$, and the thickness of the stem (with its flat lip) is $5.6 \mathrm{~mm}$. Jackson (1933:Plate 17:47) illustrates the unreconstructed De Rossett Farm pipe, without the attached ring pedestal base, and suggests the pipe had attachments below the lip for handles. A similar ring pedestal base elbow pipe has been recovered from 41CE3 in the upper Neches River basin (Perttula 2011:Figure 6-24a).

The De Rossett Farm elbow pipe has three horizontal engraved lines below the stem lip, and the remainder of the stem is covered with four horizontal rows of small tool punctations; these punctated rows do not continue onto the bowl (see Figure 7). However, there are two diagonal rows of tool punctations that extend from the distal part of the stem along the lowermost part of the bowl, and there are also four vertical rows of tool punctations on the bowl, extending from just below the bowl lip to the base of the bowl; the ring pedestal base is plain (see Figure 7).

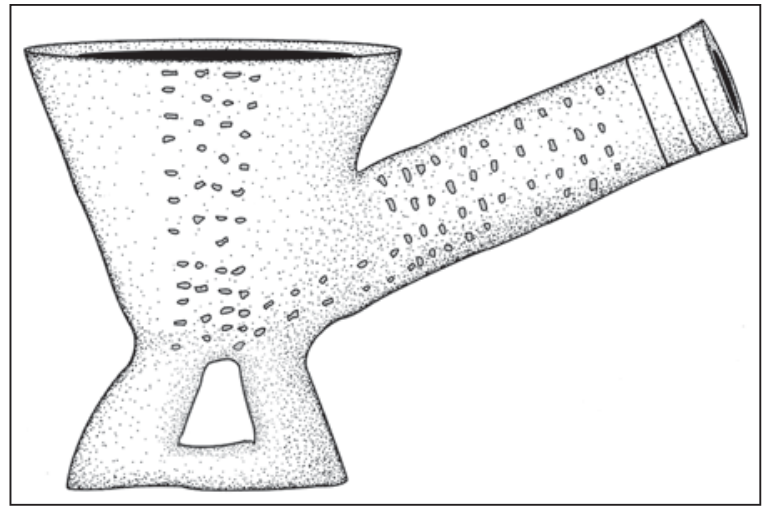

Figure 7. Incised-punctated elbow pipe from the De Rossett Farm site.

\section{Lead Artifact}

One piece of lead was recovered during the Pearce excavations in the cemetery at the De Rossett Farm site. This is a small hammered piece of lead that measured $16 \times 18 \times 2.2 \mathrm{~mm}$ in length, width, and thickness. If this piece of lead is directly associated with the burial features at the site, it would suggest that one burial feature almost certainly dates after ca. A.D. 1680, and would be of Historic Caddo age.

\section{Midden Excavations}

According to Pearce (1920a), a field next to the cemetery area was "almost covered in places with shard [sherds]." In fact, there was a midden mound ca. $100 \mathrm{~m}$ from the cemetery, and Pearce excavated a trench through its center. In this work, he noted many ceramic sherds, as well as bones of deer, squirrel, and turtle, as well as mussel shell pieces.

\section{Ceramic Sherds}

Ceramic sherds from the midden excavations at the De Rossett Farm in the TARL collections include 15 plain ware sherds, 23 fine ware sherds, and 14 utility ware sherds; they are from grog-tempered (96 percent) and bone-tempered (4 percent) vessels. A 1980s TARL inventory, however, lists 76 plain rim, body, and base sherds, 53 utility ware sherds, and 13 fine ware sherds from the site; this inventory suggests that the plain to decorated sherd ratio in the assemblage is 1.15 . Brushed sherds comprise 51 percent of the decorated sherds (and 64 percent of the utility wares).

The fine ware sherds from the De Rossett Farm site include two exterior red-slipped sherds and 21 sherds from engraved carinated bowls and bottles (Table 1). The engraved rim sherds in the assemblage have a cross-hatched engraved zone element (Figure 8a), horizontal and diagonal lines (Figure 8b), diagonal lines that are part of a Poynor Engraved vessel with a slanting scroll motif, and horizontal engraved lines. One distinctive rim sherd has engraved and excised punctated elements (Figure 8c). 
Table 1. Decorative elements on engraved sherds from the De Rossett Farm site.

\begin{tabular}{llll}
\hline Decorative element & Rim & Body & N \\
\hline $\begin{array}{l}\text { cross-hatched engraved zone } \\
\text { curvilinear engraved lines }\end{array}$ & 1 & - & 1 \\
curvilinear engraved line and opposed engraved lines & - & 1 & 1 \\
diagonal engraved lines, cf. slanting scroll el. & - & - & 1 \\
hatched triangular zone & - & 1 & 1 \\
$\begin{array}{l}\text { horizontal engraved lines } \\
\text { horizontal lines and curvilinear zone filled with small } \\
\quad \text { circular excised punctations }\end{array}$ & 3 & 2 & 1 \\
horizontal and diagonal engraved lines & - & 1 & 1 \\
horizontal line and zig-zag triangular el. with a zone & & 1 & 2 \\
$\quad \begin{array}{l}\text { of excised punctations between them } \\
\text { horizontal and vertical engraved lines } \\
\text { horizontal and vertical engraved interlocking scrolls }\end{array}$ & 1 & - & 1 \\
parallel engraved lines & & 1 & 1 \\
straight engraved line & - & 3 & 3 \\
\hline Totals & - & 2 & 2 \\
\hline
\end{tabular}

*from a bottle

**white pigment rubbed in the engraved lines

+from a carinated bowl

Another body sherd in the assemblage has both engraved and excised punctated elements (see Figure 8d), with the excised punctations in a curvilinear engraved zone. Other engraved body sherds from Poynor Engraved vessels have a vertical hatched zone (see Figure 8e) and curvilinear and opposed engraved lines (see Figure 8f). There is also one bone-tempered carinated bowl Poynor Engraved, var. $B$ sherd that has horizontal and vertical interlocking scroll elements (see Figure 8g). A proposed temporal sequence of Poynor Engraved varieties in the upper Neches River basin (see Perttula 2011:Table 6-37) suggests that var. $B$ vessels occur only in early Frankston phase contexts, from ca. A.D. 1400-1480.

Among the utility wares in the TARL collection, there are: Bullard Brushed $(n=5)$, incised $(n=2$, including a strap handle sherd with vertical incised lines on the handle), tool punctated $(\mathrm{n}=1)$, and six La Rue Neck Banded rim and body sherds. These utility wares are indicative of a Frankston phase creation and use of the midden deposits at the site.

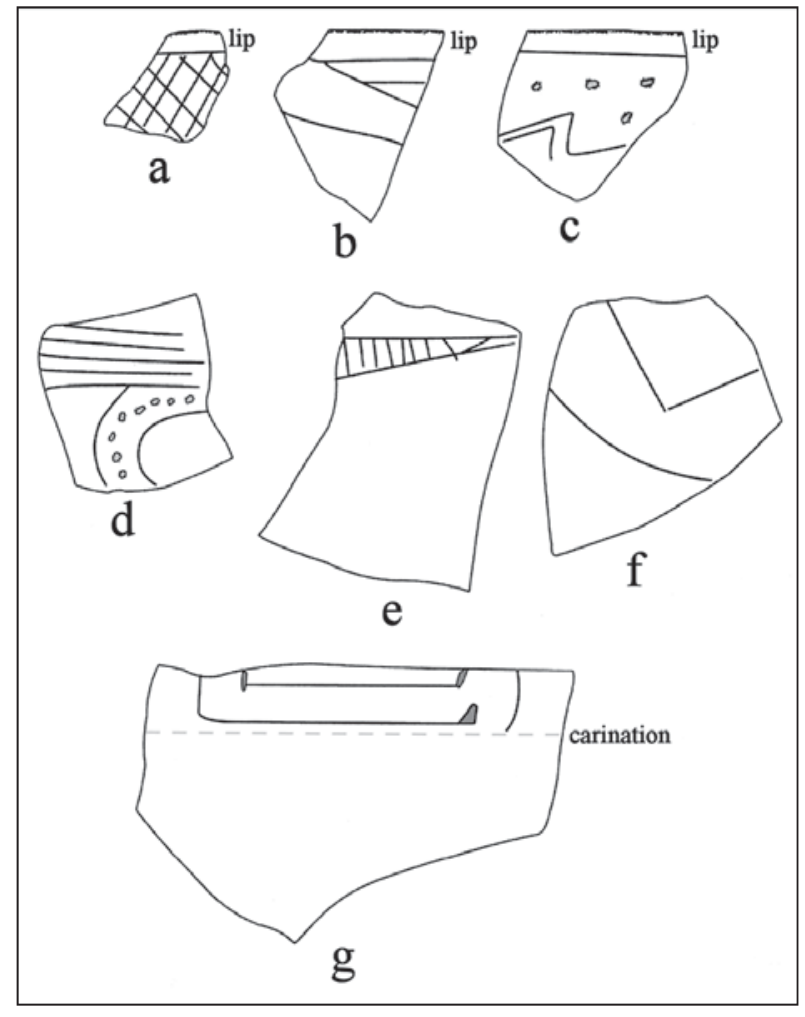

Figure 8. Selected decorative elements on engraved and engraved-punctated sherds in the fine wares from the De Rossett Farm sherd assemblage. 
Also among the sherds from the midden excavations at the site is a single plain elbow pipe bowl rim sherd. It is from a grog-tempered pipe.

\section{The Archaeology of the Quate Place (41HE81)}

Prior to completing the investigations at the De Rossett Farm, Pearce had conducted excavations in May 1920 at the Quate Place. There, Pearce had identified three distinct midden mounds, two about 200 $\mathrm{m}$ apart, and a third midden mound about $800 \mathrm{~m}$ from the other two. At least two of the midden mounds were trenched with $3 \mathrm{ft}$. wide and $2 \mathrm{ft}$. deep excavations across them. The largest of the midden mounds was $75 \mathrm{ft}$. in length, $25 \mathrm{ft}$. in width, and $2 \mathrm{ft}$. in height, and a second midden was $30 \mathrm{ft}$. in length, $10 \mathrm{ft}$. in width, and $0.7 \mathrm{ft}$. in height. Pearce described the larger midden as a "kitchen midden" with large amounts of animal bone, mussel shell, ceramic sherds, and ash.

There are 90 ceramic vessel sherds in the TARL collections from the Quate Place site. They include plain ware sherds $(n=19)$, fine ware sherds $(n=3)$, and utility ware sherds $(n=68)$. All of the sherds are from grog-tempered vessels. The plain to decorated sherd ratio in this small assemblage is 0.27 , along with the proportion of brushed sherds in the assemblage (see below), suggesting a Caddo occupation took place at the site in the latter part of the Frankston phase, between ca. A.D. 1560-1680.

Only 4.2 percent of the decorated sherds at the site are from fine ware vessels (Table 2). One of the sherds is from a bottle, and the other two are from Poynor Engraved, var. unspecified carinated bowls (Figure 9a-b). One of the carinated bowl sherds has a horizontal and diagonal engraved element on the rim panel, with a small excised triangle on the diagonal line, and vertical brushing marks on the vessel body (Figure 9b).

Table 2. Decorated sherds from the Quate Place site.

\begin{tabular}{lll}
\hline Ware & Decorative Method and Elements & N
\end{tabular}

Fine Ware

Engraved

curvilinear lines and diagonal opposed lines 1 horizontal and diagonal opposed lines $1+$

Engraved-Brushed

horizontal and diagonal engraved lines and excised tick mark, and vertical brushing on the body

\section{Utility Ware}

Brushed

Brushed-Punctated parallel brushing marks

indeterminate brushing marks

diagonal brushing and tool punctated rows through

the brushing

horizontal brushing and tool punctated rows through

the brushing

parallel brushed zones and tool punctated rows

tool punctated row at rim-body juncture and diagonal

brushing on vessel body
1

$1+$ 
Table 2. Decorated sherds from the Quate Place site, cont.

\begin{tabular}{|c|c|c|}
\hline Ware & Decorative Method and Elements & $\mathrm{N}$ \\
\hline \multicolumn{3}{|c|}{ Utility Ware, cont. } \\
\hline Incised & $\begin{array}{l}\text { cross-hatched incised lines } \\
\text { parallel incised lines/zones with hatched lines within } \\
\text { zones }\end{array}$ & $\begin{array}{l}1 \\
1\end{array}$ \\
\hline Neck Banded & $\begin{array}{l}\text { horizontal neck bands } \\
\text { parallel neck bands }\end{array}$ & $\begin{array}{l}1 \\
1\end{array}$ \\
\hline Pinched & parallel pinched ridges & 1 \\
\hline Punctated & $\begin{array}{l}\text { tool punctations along margins of lug handle } \\
\text { tool punctated rows }\end{array}$ & $\begin{array}{l}1 \\
4\end{array}$ \\
\hline Totals & & 71 \\
\hline
\end{tabular}

*tabulated from TARL inventory; +=bottle sherd

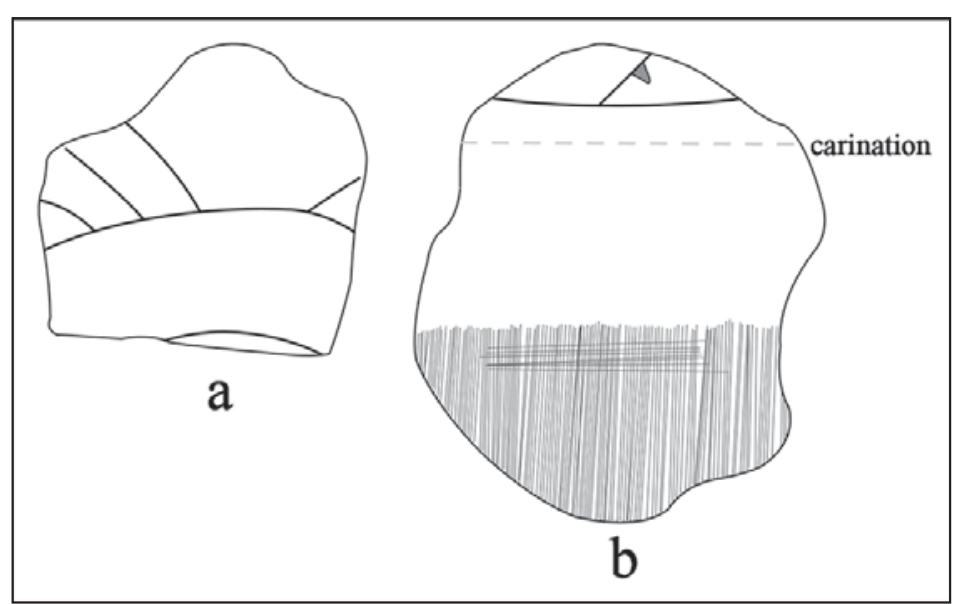

Figure 9. Decorative elements on selected engraved sherds from the Quate Place site.
More than 81 percent of all the decorated sherds from the Quate Place site, and 85 percent of the utility ware sherds, are from Bullard Brushed vessels with brushed or brushed-punctated decorative elements (see Table 2). Other utility ware sherds are from Maydelle Incised, La Rue Neck Banded, and Killough Pinched jars.

In addition to the ceramic sherds recovered from the site, there were a ceramic pipe sherd, two arrow points (Perdiz and Scallorn-like), two scraping tools, and a celt fragment made from a Ouachita Mountains igne-

ous rock. There were also bone tools - a deer ulna tool and a deer antler billet-and animal bones; these were from deer, turtle, opossum, turkey, and gar. Mussel shell valves were also recovered in the midden excavations.

Lastly, one Gary dart point and one Yarbrough dart point are in the collections from the Quate Place. They indicate use of the site likely during Woodland (ca. 500 B.C.-A.D. 800) and Late Archaic (ca. 3000500 B.C.) times.

\section{Summary and Conclusions}

The De Rossett Farm and Quate Place sites are ancestral Caddo sites in the Cobb Creek valley, a small eastward-flowing tributary to the Neches River in the East Texas Post Oak Savannah. Both sites were investigated by Dr. J. E. Pearce of UT in 1920, and are among the first sites investigated by professional archaeologists in the state of Texas. 
The De Rossett Farm site was a Caddo settlement and cemetery of unknown size, but the number of ceramic vessels recovered by Judge A. B. Watkins in 1919 and Pearce in 1920 suggests that at least four burials were excavated at the site. The settlement was marked by midden mound deposits with apparently a dense concentration of ceramic sherds and animal bones, only a few of which were recovered and retained in the UT collections. The range of artifacts from both the midden and the small cemetery, including one distinctive ring base elbow pipe, indicate that the De Rossett Farm site was occupied by Caddo peoples during Late Caddo period, Frankston phase times. The occurrence of Poynor Engraved, var. Hood carinated bowls and Hood Engraved bowls suggest that the burials were interred between ca. A.D. 1480-1560, while the midden deposits may have accumulated somewhat earlier, perhaps between ca. A.D. 1400-1480. The one piece of lead supposedly found in the burial excavations does not appear to have been in archaeological association with them, as there is no indication in the recovered funerary offerings to suggest they date from the time of European contact after the late $17^{\text {th }}$ century.

The Quate Place was an ancestral Caddo settlement with two or three midden mound deposits along the southern side of the Cobb Creek valley; dart points recovered there also indicate the site area was used during Woodland and Late Archaic times. The recovered fine ware and utility wares from the midden mounds at the Quate Place suggest that the Caddo occupation took place at the site in the latter part of the Frankston phase, between ca. A.D. 1560-1680.

\section{Acknowledgments}

Thanks to Marybeth Tomka for providing access to the collections from the De Rossett Farm and Quate Place sites at the Texas Archeological Research Laboratory at The University of Texas at Austin. Lance Trask prepared the figures in this article.

\section{References Cited}

Jackson, A. T.

1933 Indian Pipes of East Texas. Bulletin of the Texas Archeological and Paleontological Society 5:69-86.

Pearce, J. E.

1920a Explorations near Frankston, Texas. MS on file, Texas Archeological Research Laboratory, The University of Texas at Austin.

1920b Early Work in East Texas. MS on file, Texas Archeological Research Laboratory, The University of Texas at Austin.

1932a The Archaeology of East Texas. American Anthropologist 14:670-687.

1932b The Significance of the East Texas Archaeological Field. In Conference on Southern Pre-History, pp. 53-58. National Research Council, Washington, D.C.

1932c The Present Status of Texas Archeology. Bulletin of the Texas Archeological and Paleontological Society 4:44-54.

Perttula, T. K.

2011 The Ceramic Artifacts from the Lang Pasture Site (41AN38) and the Place of the Site within an Upper Neches River Basin Caddo Ceramic Tradition. In Archeological Investigations at the Lang Pasture Site (41AN38) in the Upper Neches River Basin of East Texas, assembled and edited by T. K. Perttula, D. B. Kelley, and R. A. Ricklis, pp. 145-320. Archeological Studies Program Report No. 129, Texas Department of Transportation, Environmental Affairs Division, Austin. 